\title{
RECHTSREGEL
}

Jurnal Ilmu Hukum Vol 2, No. 2 Desember 2019

P-ISSN 2622-6235, E-ISSN 2622-6243

rjih_fh@unpam.ac.id

\section{PENERAPAN PENYELESAIAN KREDIT MACET DENGAN RESTRUKTURISASI BERDASARKAN PASAL 21 PERATURAN OTORITAS JASA KEUANGAN NOMOR: 33/POJK.03/2018 TENTANG RESTRUKTURISASI (Studi Kasus di BPR Lestari Jakarta Barat),}

\section{Soleha}

Fakultas Hukum, Universitas Pamulang

Email: Soleha.0201@gmail.com

Received : 10 Sept 2019/Revised: 12 Okt 2019/Accepted: 14 Nov 2019

\begin{abstract}
ABSTRAK
Kewajiban nasabah debitur dalam perjanjian kredit adalah melunasi hutangnya dalam jangka waktu tertentu dengan sejumlah nominal yang disertai bunga. Namun demikian adanya faktor intern dan/atau ekstern, yang menyebabkan Debitur mengalami kredit macet, sehingga tidak bisa memenuhi prestasi yang telah dijanjikan sebagaimana terdapat dalam perjanjian kredit. Apabila nasabah Debitur yang mengalami kredit macet dan jika masih dimungkinkan untuk berprestasi lagi dalam memenuhi kewajibannya, maka bank biasanya akan melakukan penyelesaian secara baik yaitu menolong nasabah yang sedang mengalami kesulitan dengan melakukan penyelamatan. Adapun upaya penyelamatan yang dimaksud dapat berupa, penjadawalan kembali (rescheduling), persyaratan kembali (reconditioning), dan penataan kembali (restructuring). Tujuan penelitian ini adalah untuk menganalisis penerapan restrukturisasi kredit macet yang diatur dalam Pasal 21 Peraturan Otoritas Jasa Keuangan Nomor : 33/POJK.03/2018 dalam pelaksanaannya di BPR Lestari Jakarta Barat dan untuk mengetahui hambatan-hambatan dalam penerapan restrukturisasi kredit macet di BPR Lestari Jakarta Barat.
\end{abstract}

\section{Kata Kunci: Debitur, Kredit Macet, BPR Lestari Jakarta Barat}

\section{ABSTRACT}

The obligation of the debtor in the loan agreement is to pay off the debt within a certain period of time with a nominal amount accompanied by interest. However, there are internal and / or external factors, which cause the Debtor to experience bad credit, so they cannot fulfill the promised performance as stated in the credit agreement. If a Debtor 
customer experiences bad loans and if it is still possible to perform well again in meeting their obligations, the bank will usually make a good settlement, which is to help customers who are having difficulty with rescue. The rescue effort in question can be in the form of rescheduling, reconditioning, and restructuring. The purpose of this study is to analyze the implementation of bad credit restructuring regulated in Article 21 of the Financial Services Authority Regulation Number: 33 / POJK.03 / 2018 in its implementation at BPR Lestari West Jakarta and to determine the obstacles in the implementation of bad credit restructuring at BPR Lestari Jakarta West.

\section{Keywords: Debtor, Bad Credit, BPR Lestari West Jakarta}

\section{PENDAHULUAN}

Kegiatan pinjam meminjam sudah dilakukan sejak lama yaitu sebelum Indonesia Merdeka, dimana Pemerintah kolonial Hindia Belanda sudah memulai kebiasaan berutang bagi pemerintahan di Indonesia dan ketika Indonesia Merdeka seluruh utang yang belum dilunasinya pun turut diwariskan, sesuai dengan salah satu hasil Konferensi Meja Bundar (KMB). Penyerahan kedaulatan kepada Republik Indonesia pada waktu itu disertai dengan pengalihan tanggung jawab segala utang pemerintah kolonial. Dilihat dari perspektif utang piutang, maka Republik Indonesia bukanlah negara baru, melainkan pelanjut dari pemerintahan sebelumnya dan tradisi pengalihan utang kepada pemerintahan berikutnya bertahan sampai saat ini, artinya kegiatan pinjam meminjam memang sudah terjadi sebelum dan sesudah Indonesia Merdeka.

Menurut M. Bahsan, Kegiatan pinjam meminjam uang adalah salah satu kebutuhan manusia dimana kegiatan ini telah dilakukan masyarakat sejak masyarakat mengenal uang sebagai alat pembayaran. Hampir semua masyarakat telah menjadikan kegiatan pinjam-meminjam uang sebagai sesuatu yang sangat diperlukan 
untuk mendukung perkembangan kegiatan perekonomiannya dan meningkatkan taraf kehidupannya. ${ }^{1}$

Bagi perkembangan ekonomi suatu negara, uang merupakan suatu kebutuhan. Bahkan bagi negara maju sekalipun, uang sangat berperan dalam perkembangan ekonomi negaranya. Hal ini disebabkan karena untuk menjalankan pembangunan, uang masih dianggap sektor yang paling vital menurut tinjauan ekonomi. Uang tersebut dapat digunakan untuk mendirikan usaha-usaha kecil dan digunakan untuk keperluan lainnya. Adapun salah satu cara untuk mendapatkan uang adalah melalui kredit. ${ }^{2}$

Pengertian perjanjian dengan pengertian perikatan itu berbeda. Perikatan adalah suatu hubungan antara dua orang atau dua pihak, dimana pihak yang satu berhak menuntut sesuatu hal dari pihak lain, dan pihak lain berkewajiban untuk memenuhi tuntutan itu. ${ }^{3}$

Menurut Pasal 1(11) Undang-Undang No.10/1998 tentang Perubahan Atas UU No. 7/1992 tentang Perbankan (Undang-Undang Perbankan) sebagai berikut : Kredit adalah penyediaan uang atau tagihan yang dapat dipersamakan dengan itu, berdasarkan persetujuan atau kesepakatan pinjam meminjam antara bank dengan pihak lain yang mewajibkan pihak peminjam untuk melunasi utangnya setelah jangka waktu tertentu dengan pemberian bunga. Kemudian yang dimaksud dengan Perjanjian Kredit adalah perjanjian pemberian kredit antara pemberi kredit dan penerima kredit, setiap kredit yang telah disetujui dan disepakati antara pemberi kredit dan penerima kredit wajib dituangkan dalam bentuk perjanjian kredit

\footnotetext{
'M.Bahsan,"Hukum Jamiman dan Jaminan Kredit Perbankan Indonesia”,Raja, Grafindo Persada, Jakarta, 2008, hlm.1. hlm.20

2R.Subekti,“AnekaPerjanjian”,PT.CitraAdityaBakti, Bandung, 1995,

${ }^{3}$ R. Subekti, “Hukum Perjanjian”, Citra Aditya Bhakti, Jakarta, 1987, hlm. 1
} 
dalam Pasal 1313 Kitab Undang-Undang Hukum Perdata (KUHPer) menyebutkan perjanjian adalah suatu perbuatan dengan mana satu orang atau lebih mengikatkan dirinya terhadap satu orang lain atau lebih, ketika perjanjian yang sudah dibuat oleh kedua belah pihak atau lebih sudah memenuhi persyaratan adanya subjek yaitu para pelakunya Debitur dan Kreditur sudah memenuhi syarat sahnya perjanjian pasal 1320 KUHPerdata yaitu :

1. Adanya kesepakatan kedua belah pihak, maksud dari kata sepakat adalah kedua belah pihak yang membuat perjanjian setuju mengenai hal-hal yang pokok dalam kontrak.

2. Kecakapan untuk melakukan perbuatan hukum, asas cakap melakukan perbuatan hukum, adalah setiap orang yang sudah dewasa dan sehat pikirannya, ketentuan sudah dewasa, ada beberapa pendapat, menurut KUHPerdata, dewasa adalah 21 tahun bagi laki-laki dan 19 tahun bagi wanita, menurut undangundang nomor 1 tahun 1974 tentang perkawinan, dewasa adalah 19 tahun bagi laki-laki, 16 tahun bagi wanita dan acuan hukum yang kita pakai adalah KUHPerdata karena berlaku secara umum.

3. Adanya obyek, sesuatu yang diperjanjikan dalam suatu perjanjian haruslah suatu hal atau barang yang cukup jelas.

4. Adanya klausa yang halal dalam pasal 1335 KUHPerdata, suatu perjanjian yang tidak memakai suatu sebab yang halal, atau dibuat dengan suatu sebab yang palsu atau terlarang, tidak mempunyai kekuatan hukum.

Secara tepat, Subekti telah menjelaskan ke empat syarat itu dengan cara menggolongkannya dalam 2 (dua) bagian, yaitu:

1. Bagian ke-1: mengenai subjek perjanjian, ialah orang yang membuat perjanjian harus cakap atau mampu melakukan perbuatan hukum tersebut, ada sepakat (consensus) yang menjadi 
dasar kebebasan menentukan kehendaknya (tidak ada paksaan, kekhilafan atau penipuan).

2. Bagian ke-2: mengenai objek perjanjian ditentukan, bahwa: apa yang dijanjikan oleh masing-masing harus cukup jelas untuk menetapkan kewajiban masing-masing pihak, apa yang dijanjikan oleh masing-masing tidak bertentangan dengan undang-undang, ketertiban umum atau kesusilaan. Subekti menambahkan, bahwa tidak dipenuhinya syarat subjektif dapat dimintakan pembatalan perjanjian kepada Hakim, tetapi hal tidak dipenuhinya syaratsyarat objektif diancam dengan kebatalan perjanjian demi hukum. ${ }^{4}$

Jika sudah memenuhi kreteria seperti apa yang tertuang dalam pasal 1320 KUHPerdata, maka perjanjian sudah bisa dilakukan seperti apa yang tertera didalamnya, berdasarkan kesepakatan yang dibuat oleh para pihak, sebaliknya jika perjanjian tidak memenuhi kriteria seperti yang tertuang dalam pasal 1320 KUHPerdata, seperti contohnya para pihak yang melakukan perjanjian masih dibawah umur dan perjanjian ini masih berlangsung sampai para pihak menginjak usia dewasa sehingga memenuhi kreteria yang ditetapkan oleh undang-undang, maka para pihak bisa mengajukan pembaharuan perjanjian atau melakukan revisi perjanjian, perjanjian pinjam peminjam yang sering terjadi yaitu baik itu antar perseorangan maupun melalui badan hukum seperti proses pinjam meminjam yang terjadi di Bank antara Kreditur dan Debitur dalam jangka waktu tertentu dengan adanya jaminan atau tidak adanya jaminan, baik itu melalui bank umum dan BPR.

${ }^{4}$ Ibid, hlm. 16-17 


\section{PERMASALAHAN}

Berdasarkan uraian diatas, maka dapat dirumuskan permasalahan sebagai berikut:

1. Bagaimana penerapan penyelesaian kredit dengan restrukturisasi berdasarkan Pasal 21 Peraturan Otoritas Jasa Keuangan Nomor: 33/POJK.03/2018?

2. Bagaimana hambatan-hambatan dalam penerapan penyelesaian kredit macet dengan restrukturisasi berdasarkan Pasal 21 Peraturan Otoritas Jasa Keuangan Nomor: 33/POJK.03/2018?

\section{METODE PENELITIAN}

Dalam pengumpulan data dan bahan untuk penelitian ini digunakan metode penelitian sebagai berikut :

1. Metode Pengumpulan Data

a. Penelitian kepustakaan Penelitian kepustakaan yaitu mencari landasan teori dengan mempelajari buku-buku bacaan, bahan bahan kuliah serta artikel-artikel yang berhubungan dengan topik pembahasan.

b. Penelitian Lapangan Penelitian lapangan yaitu dengan melakukan penelitian langsung ke PT. BPR Lestari Jakarta Barat dengan melakukan wawancara dan tanya jawab guna mendapatkan data-data dan keterangan-keterangan yang erat kaitanya dengan penulisan ini.

2. Metode Analisa Data

Metode analisa data untuk menulis tugas akhir ini adalah metode deskriptif yaitu dengan menguraikan data secara sistematis dari fakta-fakta yang didapat kemudian dihubungkan dengan prosedur penyelesaian kredit bermasalah pada PT. Bank Perkreditan Rakyat (BPR) Lestari Jakarta Barat. 


\section{PEMBAHASAN}

\section{Prinsip-prinsip Penanganan Kredit Bermasalah}

Dalam menangani Kredit bermasalah, pegawai BPR yang terkait dalam perkreditan harus melakukan upaya sebagai berikut:

1. Debitur yang memiliki Kredit bermasalah dan Kredit yang berpotensi bermasalah dilakukan pembinaan lebih intensif;

2. Informasi mengenai Kredit bermasalah harus secara jelas diungkapkan dalam dokumentasi dan administrasi Kredit untuk penanganan tindak lanjut di intern BPR serta disampaikan kepada Dewan Komisaris untuk menjadi materi dalam laporan pengawasan rencana bisnis BPR oleh Dewan Komisaris kepada Otoritas Jasa Keuangan;

3. Informasi sebagaimana dimaksud pada angka 2 paling sedikit mencakup penyebab utama Kredit bermasalah, perkembangan penanganan Kredit bermasalah, serta tindak lanjut penanganan Kredit bermasalah khususnya yang berdampak signifikan terhadap kinerja BPR;

4. BPR tidak melakukan pengecualian dalam penanganan Kredit bermasalah, khususnya untuk Kredit bermasalah kepada pihak terkait dengan BPR, Debitur grup, dan/atau Debitur besar; dan

5. BPR tidak melakukan penyelesaian Kredit bermasalah dengan cara menambah plafon Kredit atau tunggakan bunga dengan cara mengkapitalisasi tunggakan bunga tersebut.

\section{Penyusunan Program Penanganan Kredit Bermasalah}

Program penanganan Kredit bermasalah harus disetujui oleh Direksi dan disusun sedini mungkin sebelum berdampak terhadap kinerja perkeditan BPR secara keseluruhan paling sedikit mencakup: 
1. Tata cara penanganan untuk setiap Kredit bermasalah sesuai dengan Peraturan Otoritas Jasa Keuangan ini maupun kebijakan BPR menangani penyelamatan dan penyelesaian Kredit bermasalah;

2. Perkiraan jangka waktu penyelesaian;

3. Perkiraan hasil penyelamatan atau jangka waktu penyelesaian Kredit bermasalah, baik dari sisi pengembalian Kredit maupun dari sisi kualitas Kredit; dan

4. Memprioritaskan penanganan Kredit bermasalah kepada pihak terkait dengan BPR, Debitur grup, dan/atau Debitur besar.

Kriteria Kredit yang dapat direstrukturisasi paling sedikit memenuhi:

1. Debitur mengalami kesulitan pembayaran pokok dan/atau bunga Kredit; dan

2. Debitur memiliki prospek usaha yang baik dan dinilai mampu memenuhi kewajiban setelah kredit direstrukturisasi.

Menurut kententuan Pasal 1 ayat (10) Peraturan Otoritas Jasa Keuangan Republik Indonesia Nomor 33/POJK.03/2018 tentang Kualitas Aset Produktif dan Pembentukan Penyisihan Penghapusan Aset Produktif Bank Perkreditan Rakyat, memberikan pengertian mengenai restrukturisasi kredit adalah upaya perbaikan yang dilakukan BPR dalam kegiatan perkreditan terhadap Debitur yang mengalami kesulitan untuk memenuhi kewajibannya, dilakukan melalui:

1. Penjadwalan kembali;

Yang dimaksud dengan "penjadwalan kembali (rescheduling)" berupa perubahan jadwal pembayaran kewajiban Debitur dan/atau perubahan jangka waktu.

2. Persyaratan kembali; dan/atau 
Yang dimaksud dengan "persyaratan kembali (reconditioning)" berupa perubahan sebagian atas seluruh persyaratan kredit.

Persyaratan kembali (reconditioning) dilakukan melalui antara lain:

a. Perubahan jadwal pembayaran;

b. Perubahan jumlah angsuran;

c. Perubahan jangka waktu;

d. Penurunan suku bunga Kredit; dan/atau

e. Penghapusan sebagian kewajiban;

3. Penataan kembali.

Yang dimaksud dengan “penataan kembali (restructuring)' berupa perubahan persyaratan kredit. Penatan kembali (restructuring) dilakukan melalui antara lain:

a. Penambahan fasilitas Kredit BPR; dan/atau

b. Konversi seluruh atau sebagian tunggakan angsuran bunga menjadi pokok kredit baru, yang dapat disertai dengan penjadwalan kembali atau persyaratan kembali.

Selanjutnya Peraturan Otoritas Jasa Keuangan Republik Indonesia Nomor 33/POJK.03/2018 tentang Kualitas Aset Produktif dan Pembentukan Penyisihan Penghapusan Aset Produktif Bank Perkreditan Rakyat mengatur mengenai tata cara, larangan, serta kewajiban dan melakukan restrukturisasi kredit sebagai berikut:

1. BPR dapat melakukan Restruktur Kredit terhadap Debitur yang memenuhi Kriteria;

a. Debitur mengalami kesulitan pembayaran pokok dan/atau bunga Kredit; dan

b. Debitur memiliki prospek usaha yang baik dan dinilai mampu memenuhi kewajiban setelah kredit direstrukturisasi. 
2. BPR dilarang melakukan Restrukturisasi Kredit sebagaimana dimaksud dalam Pasal 21, dalam hal bertujuan untuk menghindari;

a. Penurunan kualitas Kredit;

b. Peningkatan pembentukan PPAP; dan/atau

c. Penghentian pengakuan pendapatan bunga secara akrual.

3. BPR wajib menerapkan perlakuan akuntansi Restrukturisasi Kredit termasuk namun tidak terbatas pada pengakuan kerugian yang timbul dalam rangka Restrukturisasi Kredit, sesuai dengan Standar Akuntansi Keuangan dan Prinsip akuntansi Perbankan Indonesia yang berlaku.

4. BPR wajib memiliki kebijakan dan prosedur tertulis mengenai Restrukturisasi Kredit, di mana kebijakan Restrukturisasi Kredit tersebut wajib disetujui oleh Komisaris, dan Komisaris wajib melakukan pengawasan secara aktif terhadap pelaksanaan kebijakan Restrukturisasi Kredit.

5. Kualitas Kredit yang direstrukturisasi adalah:

a. Paling tinggi kurang lancar untuk kredit yang sebelum direstrukturisasi kualitasnya tergolong diragukan atau macet; atau

b. Tidak berubah, untuk Kredit yang sebelum direstrukturisasi kualitasnya tergolong lancar, dalam perhatian khusus, kurang lancar. Penggolongan kualitas kredit diatas dapat berubah menjadi:

1) Lancar, dalam hal tidak terjadi tunggakan angsuran pokok dan/atau bunga selama 3 (tiga) kali periode pembayaran secara berturut; atau 
2) Sama dengan kualitas kredit sebelum dilakukan Restrukturisasi Kredit, dalam hal Debitur tidak dapat memenuhi kondisi sebagaimana dimaksud dalam huruf a.

3) Kualitas Kredit yang direstrukturisasi dengan pemberian tenggang waktu pembayaran sebagaimana dimakasud dalam Pasal 13 ayat (1) ditetapkan:

a) Selama tenggang waktu pembayaran, kualitas Kredit mengikuti penetapan kualitas sebelum dilakukan Restrukturisasi Kredit; dan

b) Setelah tenggang waktu pembayaran berakhir, kualitas Kredit mengikuti penetapan kualitas sebagaimana dimaksud dalam Pasal 23 ayat (1) sampai dengan ayat (3).

6. Koreksi terhadap penerapan kualitas Kredit yang direstrukturisasi, pembentuk PPAP, dan pendapatan bunga yang telah diakui secara akrual, dapat dilakukan oleh Otoritas Jasa Keuangan dalam hal:

a. Berdasarkan penilaian Otoritas Jasa Keuangan, Restrukturisasi Kredit dilakukan dengan tujuan sebagaimana dimaksud dalam Pasal 22;

b. Debitur tidak melaksanakan perjanjian kredit sebagaimana dimaksud dalam Pasal 21 ayat (3);

c. Restrukturisasi Kredit dilakukan secara berulang dengan tujuan untuk memperbaiki kualitas Kredit tanpa memerhatikan prospek usaha Debitur; dan/atau

d. Restrukturisasi Kredit tidak didukung dengan dokumen yang lengkap dan analisis yang memadai mengenai kemampuan membayar dan prospek usaha Debitur. 
Sistim bank adalah kepercayaan dimana bank akan menghimpun dana dari pihak ketiga (DPK) dan menyalurkan kembali ke masyarakat yaitu dalam bentuk kredit, untuk menjamin pelaksanaan prinsip kepercayaan, antara lain bank harus menerapkan transparansi mengenai informasi setiap jenis kredit yang akan ditawarkan kepada Debitur dan calon Debitur tujuannya supaya bank bisa menimalisir resiko pada saat kredit itu bermasalah dan Debitur diberi pengetahuan sejak awal oleh pihak bank apabila kredit itu bermasalah maka pihak Debitur bisa mengajukan restruktur dengan syarat Debitur mengalami kesulitan pembayaran pokok dan/atau bunga Kredit dan Debitur memiliki prospek usaha yang baik dan dinilai mampu memenuhi kewajiban setelah Kredit direstruktur.

Artinya sikap transparansi itu dilakukan sejak awal sebelum kredit itu dicairkan tujuannya agar Debitur jadi paham jika penyelesaian kredit macet sesuai koridor hukum dapat dilakukan melalui jalur litigasi (pengadilan) dan nonlitigasi (diluar pengadilan) dan pihak bank sendiri pasti akan mengutamakan penyelesaian secara intern jika secara intern sudah tidak bisa diselesaikan maka proses penyelesaiannya yaitu eksekusi sita jaminan yaitu dengan cara penyerahan jaminan secara sukarela kepada pihak bank yaitu agunan yang diambil alih (AYDA) atau jaminannya akan dilelang. Kredit bermasalah disebabkan karena Debitur tidak sesuai komitmen untuk melakukan pembayaran setiap bulannya, hal ini bisa disebabkan karena pendapatannya menurun atau dikarenakan ada penyalahgunaan kredit .

Perjanjian utang-piutang yang berlaku khusus didunia perbankan dinamakan dengan Perjanjian Kredit. Perjanjian Kredit harus diikuti dengan Perjanjian Jaminan agar pihak bank selaku Kreditur memiliki kepastian hukum untuk mendapatkan pelunasan 
kredit, sesuai hasil wawancara dengan Pak Erik selaku pimpinan dan Pak Enden selaku Kepala Bagian Kredit terkait jaminan BPR Lestari Jakarta Barat hanya menerima jaminan dalam bentuk asset atau benda tidak bergerak yaitu Sertifikat Hak Milik (SHM) dan Sertifikat Hak Guna Bangunan (SHGB), artinya pihak bank selaku Kreditur memiliki kepastian hukum untuk mendapatkan pelunasan dimana dalam hal ini BPR Lestari Jakarta Barat memiliki batas maksimal pembiayaan (LTV) yaitu sebesar 50\% (lima puluh persen) dari nilai agunan yang dijaminkan oleh Debitur.

Kewajiban nasabah Debitur dalam perjanjian kredit adalah melunasi hutangnya dalam jangka waktu tertentu dengan sejumlah nominal yang disertai bunga. Namun demikian adanya faktor intern dan/atau ekstern, yang menyebabkan Debitur mengalami kredit macet, sehingga tidak bisa memenuhi prestasi yang telah dijanjikan sebagaimana terdapat dalam perjanjian kredit. Apabila nasabah Debitur yang mengalami kredit macet dan jika masih dimungkinkan untuk berprestasi lagi dalam memenuhi kewajibannya, maka bank biasanya akan melakukan penyelesaian secara baik yaitu menolong nasabah yang sedang mengalami kesulitan dengan melakukan penyelamatan. Adapun upaya penyelamatan yang dimaksud dapat berupa, penjadawalan kembali (rescheduling), persyaratan kembali (reconditioning), dan penataan kembali (restructuring), namun sebaliknya apabila nasabah Debitur sudah tidak bisa berprestasi lagi, maka jalur yang ditempuh adalah penyelesaian melalui jalur hukum dan ini akan memakan waktu yang lama, sebisa mungkin dari pihak BPR Lestari Jakarta Barat akan menghindari penyelesaian secara hukum karena yang lalai dalam hal ini adalah Debitur dari segala aspek apapun jika Debitur tidak memenuhi kewajibannya seperti apa yang sudah disepakati antara kedua belah pihak. 
Berdasarkan studi kasus diatas ini ada pengalihan utang atau subrogasi adalah salah satu cara yang dapat dipakai untuk mengalihkan utang piutang, subrogasi diatur dalam KUHPerdata, Buku III, Pasal 1403. Menurut Pasal 1400 KUHPerdata, subrogasi diartikan penggantian hak-hak si berpiutang (Kreditur Lama) oleh seorang pihak ketiga (Kreditur Baru) yang membayar kepada si berpiutang itu, yang terjadi baik dengan persetujuan maupun demi undang-undang.Dengan demikian dapat disimpulkan bahwa unsurunsur dalam subrogasi meliputi:

1. Ada satu Debitur yang sama

2. Ada lebih dari satu Debitur

3. Ada pembayaran dari Kreditur Baru kepada Kreditur lama

Pada praktiknya Bank memiliki ketentuan internal berupa standar kebijakan dan standar prosedur yang mengatur perihal restruktur, sehingga segala analisis dan keputusan atas persetujuan atau penolakan terhadap restruktur Debitur selain mengacu pada peraturan perundang-undangan juga akan mengacu pada ketentuan internal. Bank yang memberikan restruktur tanpa memperhatikan ketentuan kriteria diatas dapat dikenakan sanksi administrative antara lain berupa:

1. Teguran secara tertulis

2. Pembekuan kegiatan usaha tertentu, dan/atau

3. Pencantuman pengurus dan/atau pemegang saham bank dalam daftar pihak-pihak yang mendapatkan predikat Tidak Lulus dalam kemampuan dan kepatutan (lift and proper test).

Berdasarkan hasil wawancara dengan Pak Enden selaku Kepala bagian (Kabag) Kredit ini bertentangan dengan kebijakan restruktur dalam butir (b) yang menerangkan bahwa "pejabat atau pegawai yang ditugaskan dalam unit kerja atau pejabat yang ditunjuk untuk 
menangani restrukturisasi kredit tidak terlibat dalam proses pemberian kredit kepada debitur yang akan direstruktrurisasi tersebut, artinya baik itu bagian analis sebelum kredit" itu dicairkan dan ketika kredit itu bermasalah itu dilakukan dengan pejabat atau pegawai yang berbeda, untuk saat ini di BPR Lestari Jakarta Barat itu masih dilakukan dengan pejabat atau pegawai yang sama, seharusnya untuk menjaga sikap konsistensi berdasarkan jabatan ini dilakukan dengan pejabat atau pegawai yang berbeda, tujuannya agar ada perbandingan dan bisa dievaluasi apabila ada koreksi.

\section{KESIMPULAN}

1. Penerapan penyelesaian kredit dengan restrukturisasi berdasarkan Pasal 21 Peraturan Otoritas Jasa Keuangan Nomor: 33/POJK.03/2018, BPR dapat melakukan Restrukturisasi Kredit terhadap Debitur yang memenuhi kriteria yaitu Debitur mengalami kesulitan pembayaran pokok dan/atau bunga Kredit dan Debitur memiliki prospek usaha yang baik dan dinilai mampu memenuhi kewajiban setelah direstrukturisasi, adapun upaya penyelamatan yang dimaksud dapat berupa, penjadwalan kembali (rescheduling), persyaratan kembali (reconditioning), dan penataan kembali (restructuring), namun sebaliknya apabila nasabah Debitur sudah tidak bisa berprestasi lagi, maka jalur yang ditempuh adalah penyelesaian melalui jalur hukum dan ini akan memakan waktu yang lama, sebisa mungkin dari pihak BPR Lestari Jakarta Barat akan menghindari penyelesaian secara hukum karena yang lalai dalam hal ini adalah Debitur dari segala aspek apapun jika Debitur tidak memenuhi kewajibannya seperti apa yang sudah disepakati antara kedua belah pihak. 
2. Hambatan-hambatan dalam penerapan kredit macet dengan restrukturisasi Berdasarkan Pasal 21 peraturan otoritas jasa keuangan Nomor: 33/POJK.03/2018 (Studi kasus di BPR Lestari Jakarta) yaitu setelah dilakukannya restruktur debitur tidak konsisten untuk membayar angsuran sesuai kesepakatan yang dibuat oleh kedua belah pihak.

\section{SARAN}

1. Pimpinan BPR Lestari Jakarta Barat untuk proses penanganan restruktur yaitu bagian remedial lebih baik untuk bagian analisisnya yaitu pada saat pengajuan kredit dan pada saat kredit itu bermasalah lebih baik dilakukan dengan tim analisis pejabat atau pegawai yang berbeda, guna mencegah agar tidak terjadinya penyalahgunaan wewenang yaitu adanya kerjasama antara calon Debitur dan Debitur dengan bagian analisis untuk memanipulasi data atau sebagainya.Untuk bagian marketing harus transparansi mengenai informasi setiap jenis kredit yang akan ditawarkan kepada Debitur dan calon Debitur secara memadai, jelas akurat, dan dapat dibandingkan antara produk yang satu dengan produk lain sesuai hak kebutuhan Debitur atau calon Debitur."

2. Debitur harus menjalin hubungan yang baik dengan Kreditur dan lebih intens agar dapat mendeteksi lebih dini kemungkinan permasalahan, sehingga proses retsrukturisasi tidak terlambat, dan Debitur memiliki kesempatan untuk pulih. Calon Debitur dan Debitur harus lebih berhati-hati dalam memanage keuangan agar kredit macet bisa dihindarkan. 


\section{DAFTAR PUSTAKA}

\section{Buku}

Boedi Abdullah, 2016, Hukum Perbankan di Indonesia, Bandung: Pustaka Setia.

Hassanuddin Rahman, 1998, Aspek-Aspek Hukum Pemberian Kredit Perbankan, Bandung: PT. Citra Aditya Bakti.

Ismail, 2010, Manajemen Perbankan: Dari Teori Menuju Aplikasi, Jakarta: Kencana.

Ikatan Bankir Indonesia (IBI), 2016, Strategi Manajemen Risiko Bank, Jakarta: PT. Gramedia Pustaka, Edisi PertamaSeptember.

Ikatan Bankir Indonesia (IBI), 2016, Manajemen Kesehatan Bank Berbasis Risiko, Jakarta: PT. Gramedia Pustaka, Edisi Pertama-September.

Iswi Hariyani, 2010, Restrukturisasi dan Penghapusan Kredit Macet, Jakarta: PT. Alex Media Komputindo.

J. Satrio, 1999, Hukum Perikatan Perikatan Pada Umumnya, Bandung: Alumni.

Julius R. Latumaerissa, 2014, Manajemen Bank Umum, Jakarta: Mitra Wacana Media.

Kasmir, 2016, Manajemen Perbankan, Jakarta: PT. Raja Grafindo Persada

M.Bahsan, 2008, Hukum Jamiman dan Jaminan Kredit Perbankan Indonesia, Jakarta: Raja Grafindo Persada,.

Munir Fuadi, Muchtar Wahid, 2008 , Memaknai Kepastian Hukum Hak Milik Atas Tanah, Suatu Analisis dengan Pendekatan Terpadu Secara Normatif dan Sosiologis”, Jakarta: Republika.

Malayu SP Hasibuan, 2007, Dasar-Dasar Perbankan, Jakarta: Bumi Aksara,

Iqbal, M. (2019). EFEKTIFITAS HUKUM DAN UPAYA MENANGKAL HOAX SEBAGAI KONSEKUESNI NEGATIF 
PERKEMBANGAN INTERKASI MANUSIA. Literasi Hukum, 3(2), 1-9.

Trisadini P. Usanti, Abd. Shomad, 2017, Hukum Perbankan, Depok: Kencana, September.

Panggabean, 2012, Praktik Standard Contract (Perjanjian Baku dalam Perjanjian Bermasalah, Bandung: PT. Alumni.

Punama TioriaSianturu, 2010, Perlindungan Hukum Pembeli Barang Jaminan Tidak Bergerak Melalui Lelang, Bandung: Mandar Maju.

R. Subekti, 1995, Aneka Perjanjian, Bandung: PT. Citra Aditya Bakti

R. Subekti, 1987, Hukum Perjanjian, Jakarta: Citra Aditya Bhakti,.

\section{Peraturan Perundang-undangan}

Kitab Undang-Undang Hukum Perdata

Peraturan Otoritas Jasa Keuangan Republik Indonesia Nomor : 33/POJK.03/2018

\section{Artikel Seminar/Jurnal/Website}

Saraswati, Rosita Ayu. "Peranan Analisis Laporan Keuangan, Penilaian Prinsip 5C Calon Debitur dan Pengawasan Kredit terhadap Efektivitas Pemberian Kredit pada PD BPR Bank Pasar Kabupaten Temanggung." Nominal, Barometer Riset Akuntansi dan Manajemen 1.1 (2012).

Ambarsita, Luluk. "Analisis penanganan kredit macet." Manajemen Bisnis 3.1 (2014).

Suartama, I. Wayan, et al. "Analisis Penerapan Restrukturisasi Kredit Dalam Upaya Penyelamatan Non Performing Loan (NPL) Pada PT BPR Nusamba Tegallalang." JIMAT (Jurnal Ilmiah Mahasiswa Akuntansi) Undiksha 8.2 (2017). 
Soleha

Yasa, Gede Bangbang Mertha, and I. Nyoman Surata. "Penyelesaian Kredit Macet Melalui Novasi Pada Pt Bpr Padma Cabang Singaraja." Kertha Widya 4.2 (2019).

Nim, Rismawati. "Tinjauan Yuridis Penerapan The Five C's Of Credit (5c) Dalam Analisis Pemberian Kredit Di Pt. Bank Perkreditan Rakyat Lokadana Sentosa Sungai Raya Kabupaten Kubu Raya." Jurnal Fatwa Hukum 1.1. 